\title{
Biblioteca pública, memória e representações sociais: o depoimento de um grupo de usuários acerca da Mário de Andrade *
}

\author{
Fabrício José Nascimento da Silveira **
}

Artículo recibido:

18 de abril de 2012.

Artículo aceptado:

27 de junio de 2012.

\section{RESUMEN}

El presente artículo analiza la participación de las bibliotecas públicas en el proceso de construcción de memorias sociales compartidas relacionalmente a partir de una perspectiva representacional. Cuadro de sentido compuesto a través del análisis de un conjunto de testimonios y relatos de vida colectados y puestos a la disposición del público por el Proyecto Memoria

* Este artigo sintetiza alguns resultados de uma pesquisa de doutoramento que vem sendo desenvolvida junto ao Programa de Pós-Graduação em Ciência da Informação/PPGCI/UFMG. Com o título: De "teatro da memória" a "espaço de representações sociais": a participação das bibliotecas públicas no processo de constituição de referenciais identitários, o trabalho tem orientação da Profa. Dra. Alcenir Soares dos Reis, a quem agradeço as considerações e leitura prévia do mesmo.

** Doutorado em Ciência da Informação pelo PPGCI/UFMG, Brasil. fabrisilveira@ gmail.com

INVESTIGACIÓN BiBLIOTECOLÓGICA, Vol. 26, Núm. 57, mayo/agosto, 2012, México, ISSN: 0187-358X. pp. 199-231 
Oral de la Biblioteca 'Mário de Andrade', programa que tiene como objetivo profundizar el entendimiento acerca de la historia de la institución y mejor comprender sus caminos y descaminos en el ámbito de la vida cultural paulistana. Por lo general, tales relatos permiten que el que presenta su testimonio en foco reflexione sobre su formación como sujeto histórico y sobre las relaciones que mantiene/mantuvo con la ciudad sede de la biblioteca (actividades, estrategias de movilización y relaciones práctico-afectivas). Posibilita, incluso, que el mismo sujeto aborde cuestiones relativas al lugar ocupado por la Biblioteca Mário de Andrade (BMA) -dimensiones históricas, simbólicas y estructurales- en todo ese proceso formativo-relacional. Amparado por un análisis procesal de los relatos, la memoria social erigida en torno y a partir de la BMA puede ser revelada a través de la asociación de los eventos, situaciones y representaciones que aparecen de manera recurrente en las narrativas de los entrevistados.

Palabras-clave: Biblioteca pública; Memoria social; Representaciones sociales; Biblioteca Mário de Andrade; Proyecto Memoria Oral; Estudio de usuarios.

\section{ABSTRACT}

Public library, memory and social representations: testimonies of users about 'Mário de Andrade' Library Fabrício José Nascimento da Silveira

This article analyzes the roll of public libraries in the process of construction of collective memories that are relationally shared from a representational point of view. A 'meaning frame' is outlined by means of an analysis from a set of life testimonies and accounts which were collected and made available by the Oral Memory Project of Mário de Andrade Library. The project aims to dig in the comprehension about the institution's history and to understand better the institution's paths and detours in São Paulo's cultural life. Generally, such statements allow that the deponents reflect on their formation as historical subjects and on the relationships that they established with the city where the library lies (activities, mobilization strategies, and practical-affective relationships). They also made possible 
that the deponents address issues which refer to the place occupied by Mário de Andrade Library -historical, symbolic and structural dimensions- in all this relational-formative process. By means of a procedural analysis of the testimonies, the social memory that was constructed from and around the library could be revealed through associations of events, situations and representations that appear frequently in the deponents' discourses.

Key Words: Public library as social memory; Social representations; Mário de Andrade Library; Oral Memory Project; Users studies.

\title{
I. INTRODUÇÃO
}

\author{
Uma biblioteca, \\ em última instância, \\ só adquire sentido \\ pelo trabalho de seus leitores. \\ (ЈАСов, 2000, P.II).
}

E nunciada ao acaso, essa afirmativa certamente poderia soar como um arrece, ela nos abre inúmeros caminhos interpretativos e se mostra portadora de grande potencial heurístico. Em termos mais explícitos, o que ela parece querer nos mostrar é que atribuir um olhar investigativo ao conjunto das práticas, ações e fazeres a partir do qual as muitas modalidades de interação entre leitores, usuários e bibliotecas se dão a ver, converte-se, num plano mais geral, em valioso exercício analítico e de apreensão do lugar social ocupado por tais instituições. Exercício analítico e de apreensão que, em outra mirada, deixaria transparecer a importância dessa relação para os processos de constituição e disseminação dos referencias históricos, políticos e culturais que amparam a conformação de um universo simbólico compartilhado a partir dos livros, dos documentos informacionais ou ainda através das palavras lavradas por poetas e contadores de estórias.

Isto porque, mais que uma coleção de livros formada ao sabor do tempo e de seus patrocinadores, as bibliotecas carregam consigo a marca de injunções e paradoxos: geralmente concebidas a partir de uma pretensão utópica -fazer coabitar em um mesmo espaço todos os traços do pensamento confiados à escrita- elas 
invariavelmente se mostram subordinadas a uma série de diretrizes políticas, técnicas, ergonômicas e intelectuais que acabam impondo-lhes um sem número de restrições e reajustes. Não por acaso:

A história das bibliotecas no Ocidente é indissociável da história da cultura e do pensamento, não só como lugar de memória no qual se depositam os estratos das inscrições deixadas pelas gerações passadas, mas também como espaço dialético no qual, a cada etapa dessa história, se negociam os limites e as funções da tradição, as fronteiras do dizível, do legível e do pensável, a continuidade das genealogias e das escolas, a natureza cumulativa dos campos do saber ou suas fraturas internas e suas reconstruções. (Jacob, 2000, p.11).

História antiga cujas bases edificam-se amparadas sobre a carga simbólica de dois grandes ícones: Babel e Alexandria. O primeiro, um império de signos moldado segundo as regras de um sinuoso jogo de espelhos dispersos simetricamente em um labirinto, acena para os perigos do conhecimento e nos diz que as bibliotecas podem, segundo os interesses daqueles que as manipulam, tornar-se o lugar do desespero e do desencontro, da profusão de línguas que não promovem nenhuma espécie de entendimento.

Em um pólo oposto está Alexandria. Portadora de uma vocação universalista e se apresentando como o lugar de "cura da alma", essa biblioteca, tão fantástica quanto a primeira, ilustra as eternas tensões e contradições que se instauram entre o puro prazer de acumulação e as necessidades de racionalização, organização e mediação do conhecimento. Mais que isso, resultante de um esforço coletivo, Alexandria emerge como protótipo e modelo de todas as suas sucessoras. Isto é, estabelece em torno de si e em função das necessidades de seus leitores e usuários uma nova relação com o tempo e com o espaço: tempo da acumulação e espaço de socialização daquilo que foi acumulado; tempo de proliferação do saber e espaço de produção de conhecimento; tempo de desejo, de posse e de conservação e espaço de experiências individuais e coletivas que nos relembram com certa insistência "que as bibliotecas são frágeis e mortais, como os homens e as civilizações das quais elas são guardiãs”. (Goulemot, 2011, p.37).

Eis o que também apreendemos quando iniciamos uma incursão pela história das bibliotecas públicas. Instituições com passado recente - surgem em uma Inglaterra marcada pela efervescência da Revolução Industrial - mas que rapidamente se fazem notar como espaços que influenciam e são influenciados pelas estruturas e dinâmicas sociais que os circundam, refletindo e contribuindo para o seu desenvolvimento através da coleta, organização e disseminação dos produtos culturais; da administração e produção do conhecimento 
registrado; além da garantia de livre acesso a todos aqueles que queiram utilizá-los. Razão pela qual se aponta, quase como um consenso, que "o adjetivo público, que contemporaneamente se juntou ao nome da biblioteca, não corresponde apenas ao desejo de identificá-la como organismo mantido pelo governo ou por entidades particulares, mas aberto a todos os interessados". (Martins, 2002; p.325).

Portanto, longe de se definirem como depósito ou cofre onde se preservam livros, documentos informacionais e qualquer outro insumo capaz de portar certos traços visíveis do fazer racional humano, as bibliotecas públicas, em virtude de seu potencial democrático, congregador e socializante, acabam por desempenhar um papel essencial na vida das sociedades modernas: é em volta delas que se exibem todas as outras dimensões da existência social que necessitam do conhecimento para se constituírem, nutrirem-se e ganharem visibilidade. Visibilidade que, em última instância e conforme salientado, só se torna perceptível por meio do trabalho de seus interlocutores.

Argumento passível de ser observado/aferido através de uma série de estratégias metodológicas: análise e descrição das comunidades de leitores que se formam/formaram a partir destas instituições; comparação dos índices de freqüência e usabilidade alcançados pelas bibliotecas em relação aos demais organismos culturais disponíveis em uma dada localidade; avaliação da escala de satisfação da população tanto em relação ao acervo, à infra-estrutura física, quanto aos serviços por elas prestados. Além desses, pode-se edificar um valioso panorama analítico das modalidades de inserção das bibliotecas públicas nos domínios da vida cultural, política e histórica de um determinado grupo de sujeitos ou mesmo de uma coletividade inteira, identificando certos eventos, situações e representações que perpassam, ajudam a configurar e mobilizar as matrizes de uma memória social erigida em torno de uma instituição específica e de seu acervo. É exatamente isso que pretendemos fazer nas páginas que se seguem.

Adotando como objeto empírico o relato de vida de 8 (oito) personalidades imersas na cena intelectual paulistana ${ }^{1}$, o presente artigo se propõe a identificar alguns traços discursivos e representacionais projetados de forma recorrente por esse grupo de sujeitos acerca da Biblioteca Pública Mário de Andrade. Os depoimentos foram todos concedidos ao Projeto Memória Oral

1 São eles: Anna Verônica Mautner (psicanalista); Aziz Ab’Saber (geógrafo e professor universitário); Fernando Henrique Cardoso (sociólogo, professor universitário e Ex-Presidente da República); Ignácio de Loyola Brandão (escritor); Jean-Claude Bernardet (crítico de cinema); Marilena Chauí (filósofa, professora universitária e Ex-Secretária de Cultura de São Paulo); Mario Chamie (poeta, ensaísta e Ex-Secretário de Cultura de São Paulo) e Ruth Cardoso (antropóloga e professora universitária). 
da Biblioteca Mário de Andrade ${ }^{2}$ e estruturados de modo a permitir que o depoente em foco reflita sobre sua formação enquanto sujeito histórico; sobre as relações que mantém com a cidade sede da biblioteca e que o mesmo aborde, ainda, questões referentes ao lugar ocupado pela biblioteca Mario de Andrade - dimensões históricas, simbólicas, estruturais e afetivas - em todo esse processo formativo-relacional.

Ampara esse exercício investigativo uma discussão teórico-conceitual concernente aos campos da memória social e das representações sociais, tendose em vista estruturar chaves de leitura que delineiem de maneira mais clara a importância e o lugar cultural ocupado pelas bibliotecas públicas no mundo contemporâneo, ajudando-nos, assim, a melhor explicar porque as mesmas só adquirem sentido em função dos trabalhos, práticas e fazeres levados a cabo por seus distintos leitores e usuários. Para tanto, comecemos por explicitar as relações de proximidade mantidas pelas bibliotecas públicas com o universo dialógico e subjetivo da memória social.

\section{BiBLIOTECA PÚBLICA E MEMÓRIA SOCIAL: PROPOSIÇÕES A PARTIR DE UMA PERSPECTIVA RELACIONAL}

A memória é, sim, um trabalho sobre o tempo, mas sobre o tempo vivido, conotado pela cultura e pelo indivíduo.

(Bosi, 2003, P.53).

O "breve século XX", entre tantas outras acepções que o sintetiza, talvez possa ser definido como o século da memória, sendo mais preciso: como o século à procura por edificar narrativas mnemônicas. Proposição calcada no aparecimento e na vertiginosa ascensão de uma "cultura da memória" que passou a povoar o imaginário social já nos primeiros anos da década de 1950 e ganhou acentuado relevo nos mais distintos campos de atuação humana ainda no limiar do século XXI.

2 O Projeto Memória Oral da Biblioteca Mário de Andrade foi idealizado como parte das comemorações dos 80 anos de existência da BMA e do processo de revitalização pelo qual a instituição vem passando desde 2005. Até o momento foram colhidos pouco mais de 50 depoimentos de personalidades do meio intelectual paulista e também de diretores e funcionários que trabalharam/trabalham na instituição. Todos os depoimentos encontram-se transcritos e disponibilizados para consulta pública no site da própria biblioteca: www.bma.sp.gov.br. 
Exibindo-se através de uma multiplicidade de fatores sócio-políticos e culturais $^{3}$, esse movimento contemporâneo em torno da valorização da memória e de certos referenciais mnemônicos fez emergir para a cena pública uma profícua e multidisciplinar agenda de pesquisa cujo elemento unificador ressalta a tentativa de se projetar um rastro de compreensão sobre as seguintes questões: o que é a memória e como ela se constitui? É possível pensarmos em memórias coletivas/sociais? Se sim, quem as produz e a quem representam? Que recursos e quais referenciais simbólicos são utilizados para preservá-las, disseminá-las, atualizá-las ou mesmo negá-las?

Impulsionadas por tais inquietações e também pela constatação de que o desejo de memória é um fenômeno que atravessa e marca a vida social, as ciências humanas elaboraram, sobretudo nos últimos 60 anos, uma vasta gama de estudos e experimentos focados em conhecer melhor os processos e atores que intervêm na constituição, na preservação, na atualização e na disseminação dos referenciais simbólicos através dos quais o trabalho mnemônico se legitima enquanto uma das preocupações culturais e políticas centrais das sociedades ocidentais.

Situando-se no cerne dessa démarche, análises com viés filosófico, psicológico, histórico e sociológico começam a demonstrar que, para além da propriedade de conservar informações, imagens e sensações representadas como passadas, a memória se exibe como um constructo social sujeito a flutuações, transformações e mudanças constantes. Isto porque, o trabalho da memória é essencialmente de elaboração, sendo mais preciso: de reelaboração de uma experiência de vida a partir do reconhecimento e da reatualização de uma lembrança.

Dinâmica que só se torna possível através do contato com a realidade presente, uma vez que utilizamos conhecimentos acumulados para lidarmos com situações novas, que se encontram unidas a novas lembranças. Estas, por sua vez, estão associadas à maneira de pensar de tantos outros que fizeram e que ainda fazem parte de nossa história. A memória é, pois, segundo estes enunciados, um produto elaborado coletivamente através dos fazeres de indivíduos que interagem, se relacionam entre si no presente. Nestas circunstâncias, nossas lembranças do passado:

3 Entre os quais vislumbramos: o fim das ditaduras na América Latina e a independência dos países africanos; a queda do Muro de Berlim; o colapso da União Soviética e o acirramento das disputas étnicas em várias regiões do Leste Europeu; o surgimento da literatura de testemunho como resposta às tentativas de negar o holocausto; a intensa política de restauração dos centros urbanos e históricos das grandes cidades européias; a criação e revitalização de museus, arquivos, bibliotecas, monumentos e celebrações públicas; o aumento do interesse por obras biográficas, bem como o crescente foco nas histórias de minorias e políticas de identidade, entre tantos outros. 
[...] por mais que pareçam fruto de sentimentos e pensamentos exclusivamente individuais, somente existem como parte de estruturas ou contextos sociais. A lembrança do passado, portanto, não é o ato individual de recordar, mas o resultado de laços de solidariedade, e, como tal, só pode existir porque foi constituída em relação a todo um conjunto de noções e convenções comuns, presentes em pessoas, grupos, lugares, datas, palavras e formas de linguagens das quais nós fazemos ou fizemos parte. (Santos, 2002; p.131).

Dito de outra maneira: embora o indivíduo seja concebido como o agente do ato de lembrar, a natureza daquilo que é lembrado é profundamente marcada por aquilo que foi compartilhado com outros, de forma que aquilo que é lembrado é sempre a memória de um passado intersubjetivo, de um tempo passado e vivenciado em relação a outras pessoas. Não por acaso, segundo Middleton \& Brown (2006, p.73-74), o trabalho de lembrar - e, portanto, de nos produzirmos enquanto pessoas que possuem um passado, uma história pessoal - está necessariamente imbricado com, e é constituído por grupos e formas culturais das quais participamos. O que implica ressaltar que:

A memória opera com grande liberdade escolhendo acontecimentos no espaço e no tempo, não arbitrariamente, mas porque se relacionam através de índices comuns. São configurações mais intensas quando sobre elas incide o brilho de um significado coletivo. (Bosi, 2003, p.31).

Significados, índices, discursos, acontecimento, objetos e práticas que, por sua vez, são produzidos e disseminados através de repertórios simbólicos demasiadamente amplos que em momento algum podem ser interpretados como se possuíssem apenas um sentido. Ou seja, independente se originário do seio familiar, das reuniões de sindicatos, das práticas escolares ou de manifestações político-religiosas, é o movimento de apropriação destes repertórios simbólicos que possibilita ao sujeito, e mesmo a uma coletividade inteira mobilizar os quadros sociais a partir dos quais sua memória se referencia, alimenta-se e produz representações para si e para o outro. Ampliando essa modalidade de compreensão:

Memória e lembrança, como pensamentos ou idéias, são vinculadas a pessoas e não pairam em um mundo virtual impessoal, como se possuíssem vida própria. Nenhum de nós pode referir-se, propriamente, às lembranças dos outros, pois essas são dos outros; uma vez mais: mesmo que a ocorrência referida seja a mesma. A solidariedade entre os integrantes de uma mesma comunidade é, por conseguinte, decorrência da construção social da memória comum. (Martins, 2007, p.38). 
A memória é, pois, algo que atravessa, que marca, que estabelece pontos de convergências entre um eu individualizado e certos referentes históricos, culturais e sociais compartilhados coletivamente. Ao fazer isso, ela acaba por possibilitar a emergência de laços de solidariedade que instituem um lugar no mundo tanto para o sujeito que lembra/recorda, quanto para o grupo que lhe permite experienciar um sentimento de pertença.

De acordo com esta prerrogativa, nenhum indivíduo lembra "sozinho", ele sempre o faz a partir das lembranças pertencentes ao grupo. Lembranças que, por sua vez, se modulam através dos códigos, normas, regras e valores que permeiam, informam e sustentam a vida coletiva. Assim, a afirmação de que a memória é coletiva está baseada no pressuposto de que as percepções individuais do passado estão sempre relacionadas a quadros de sentidos estruturados com aporte das experiências sociais ${ }^{4}$.

Postulado que, ao aliar-se à percepção de que a memória não é um constructo estável e completamente fechado sobre si mesmo, estando, em virtude disso, sujeita a flutuações, usos e contra-usos no tempo e nos espaços onde se exibe e é experienciada, instituiu-se como marco justificador para o movimento contemporâneo de proliferação dos "lugares de memória" 5 . Figurações físicas e/ou simbólicas que, dado a incapacidade da memória reter voluntariamente a totalidade das experiências humanas, fazem ressaltar a necessidade

4 Essa noção de memória social estruturada relacionalmente faz referência direta aos trabalhos do sociólogo Maurice Halbwachs: Les cadres sociaux de la mémoire (1925) e La memóire collective (1950), e ao estudo pioneiro, no Brasil, de Ecléa Bosi, Memória e sociedade: lembrança de velho (1979) segundo os quais a memória forjada coletivamente "tira sua força e sua duração do fato de ter por suporte um conjunto de homens, não obstante eles serem indivíduos que se lembram, enquanto membros do grupo" (halbwachs, 2006, p. 51). Nesse sentido, para ambos, a memória é construída, elaborada, através dos processos que promovem a interação das rememorações dos indivíduos no seio de uma esfera coletiva. Em outras palavras: as lembranças são resultados das relações das pessoas entre si, não podendo ser apenas uma aptidão pessoal. A constituição do sujeito da memória se daria, pois, no confronto das imagens pessoais com o "outro", num processo contínuo de transformações e mudanças. Em síntese: a memória não pode ser, portanto, um constructo exclusivamente individual porque contém as lembranças anteriores do grupo.

5 Expressão tradicionalmente ligada à coletânea Les lieux de mémoire, organizada pelo historiador francês Pierre Nora entre os anos de 1984 e 1992, que adotou para si a tarefa de demonstrar que o movimento de socialização dos repertórios mnemônicos na contemporaneidade está diretamente relacionado à sua impregnância em marcos físicos e simbólicos que acabam por promover uma espacialização tanto da memória quanto da identidade, inserindo-se assim no âmbito das estratégias de reivindicação por um complexo direito ao reconhecimento de si. Para além disso, este empreendimento possui ainda o mérito de ter demonstrado que entender os "lugares de memória" como manifestações de um acontecimento ou de uma lembrança cristalizada no tempo não é suficiente se não se leva em consideração os usos e os contra-usos que a dinâmica social lhes impõe. Sendo mais preciso: que arquivos, museus, bibliotecas, monumentos, símbolos e datas nacionais, festas comemorativas, santuários e coleções são lugares de memória cujo referencial mnêmico-identitário nasce e se instaura em um campo de batalhas onde o presente se debate com o passado como artifício para se edificar um futuro modulado e atravessado por ressonâncias coletivas, por isso sua força política, ideológica, histórica e cultural. 
de se criar arquivos; museus; bibliotecas; coleções; monumentos; organizar celebrações públicas e pronunciar elogios funerários como recurso de articulação social dos insumos concebidos para representar coletivamente as ações que vivenciamos no mundo e que imprimimos sobre o mundo. Todo lugar de memória é, pois,

um lugar duplo; um lugar de excesso, fechado sobre si mesmo, fechado sobre sua identidade; e recolhido sobre seu nome, mas constantemente aberto sobre a extensão de suas significações (Nora, 1993; p.27.).

Edificar "lugares de memória" significa, de acordo com esta perspectiva, atribuir-lhes uma dupla função: a de demonstrar que a constituição de discursos mnemônicos é um fenômeno estruturado socialmente e a de reforçar, seja teórica ou factualmente, a tese de que a memória, por mais adjetivos que encontre em seu caminho (individual ou coletiva; histórica, social, política ou psicológica), resiste às reduções impostas pelos enunciados contemporâneos que defendem o fim da história e a desarticulação das interações simbólicas forjadas no nível do social.

Isto porque, todo lugar de memória possui, a um só tempo, 3 (três) dimensões: uma material, cujos contornos demográficos se postam como representantes dos anseios e das necessidades de uma coletividade específica; outra de caráter simbólico que retrata um acontecimento experienciado ou imaginado por indivíduos em interação e, por fim, uma funcional que garante a cristalização/condensação das lembranças e sua transmissão, bem como a edificação de laços de sociabilidade enraizados seja no concreto, no espaço, no gesto, na imagem ou no objeto.

É o que acontece com as bibliotecas, especialmente com as públicas, cuja função social está diretamente ligada à missão de preservar, organizar e disseminar os elementos culturais e os insumos de conhecimentos concebidos por nosso fazer racional. O que implica ressaltar, segundo Serrai (1975, p.141-161), que à memória biológica, que pertence à espécie, e à memória cerebral, que pertence ao indivíduo, acrescentou-se a biblioteca como memória coletiva das experiências existenciais, científicas e culturais do lugar onde se insere.

Inscrita sob a forma de documento, esta memória requer sua reunião, organização e meios específicos para sua disseminação tendo-se em vista fomentar um amplo uso por parte de todos aqueles que contribuem para sua formação. Ou seja: captar, conservar e compartilhar o conhecimento do mundo e de nós mesmos são alguns dos poderes (e perigos) que as bibliotecas nos oferecem. Com isso, se memória é capaz de inspirar, recuperar a graça do tempo, distender conceitos duros, devolver o entusiasmo pelo que 
era caro e se perdeu, redimir o sagrado e devolver não simplesmente o passado, mas o passado que prometia, as bibliotecas se configuram como espaços onde o homem, sua herança cultural, seu patrimônio simbólico, sua tradição e sua memória social se mesclam na tentativa de superar o esquecimento e se preservarem futuro adiante. Característica que lhes conferem o status de lugares de continuidade e de preservação da história em tempos e espaços específicos. Não por acaso, toda biblioteca é, ao menos à primeira vista:

Espaço da conservação do patrimônio intelectual, literário e artístico, uma biblioteca é também o teatro de uma alquimia complexa em que, sob o efeito da leitura, da escrita e de sua interação, se liberam as forças, os movimentos do pensamento. É um lugar de diálogo com o passado, de criação e inovação, e a conservação só tem sentido como fermento dos saberes e motor do conhecimento, a serviço da coletividade inteira. (Jacob, 2000; p.9).

Papel, função ou missão que pode ser apreendida por vários ângulos: como instrumento de representação social; enquanto espaço de disputas políticas e ideológicas; pela participação que assumem no processo de conformação dos sistemas educativos; bem como pelo potencial e pela responsabilidade que incorporam como mecanismos de preservação, organização e disseminação das diversas referências materiais e imateriais através das quais nossa memória social e nosso patrimônio cultural se fazem notar. Afirmativa cuja sustentação pode ser melhor amparada se correlacionarmos a ela certos indícios históricos diretamente responsáveis pelo surgimento e pela dinamização das bibliotecas públicas enquanto um dos mais vigorosos organismos culturais da contemporaneidade.

Como já salientado anteriormente, a história das bibliotecas públicas é relativamente recente. Elas surgem na Europa como resultado de inúmeras transformações decorrentes do expressivo processo de desenvolvimento industrial e urbano que ocorreu naquela região entre os séculos XVIII e XIX. A expectativa era que tais instituições contribuíssem de maneira significativa para o progresso cultural e intelectual da nação, bem como para a promoção da ordem social. Em virtude disso, logo adotaram como uma de suas principais funções a tarefa de elaborar e auxiliar as políticas públicas ligadas à promoção da cultura, da memória, da leitura e das atividades educativas.

Quadro de referências que acaba por demarcar como função de toda biblioteca pública colaborar para a difusão e visibilidade da ampla gama das manifestações culturais humanas, sem se levar em consideração critérios ligados à etnia, crença religiosa, condição financeira, questões sexuais ou políticas, propiciando a qualquer usuário amplo acesso aos vários signos preservados em 
seus acervos, tendo-se em vista contribuir para a consolidação e disseminação do conhecimento. Devem fazer isto não apenas através de uma estrutura rígida de coleta e organização de materiais informacionais, mas também por meio de atividades lúdicas e recreativas que promovam o surgimento de uma atmosfera propícia ao exercício da imaginação e da criatividade. Devem, ainda, contribuir para o reforço e equalização das práticas educativas, não como substituta da escola, mas como esfera que comporta grandes potencialidades pedagógicas.

Assertivas que apontam para a necessidade das bibliotecas públicas priorizarem o fortalecimento do diálogo intercultural, bem como facilitar o desenvolvimento de habilidades ligadas ao uso da informação e dos insumos informacionais preservados em seus acervos. Acenam também para a expectativa de que tais instituições se posicionem, ainda, como local propício para a construção do conhecimento por intermédio do apreço à arte e às inovações científicas a fim de colocá-las a serviço de toda uma coletividade.

Portanto, seja como espaço físico, como símbolo de uma ordem cósmica ou social, ou como forma visível da razão e da memória humana, as bibliotecas, em especial as públicas, se apresentam como instâncias que guardam histórias e despertam o fascínio e o encantamento. Lugares onde tais elementos se transmutam, perturbando e excitando fantasias, irmanando o sonho com a ação, além de provocarem medo e instigarem reações.

Histórias, sonhos, fantasias, medo e encantamento que acabam se convertendo, juntamente com as ações práticas que desenvolvem em função das necessidades de seus leitores e usuários, em referenciais moduladores e mobilizadores de um sem número de discursos, referenciais mnemônicos e representações sociais para as bibliotecas públicas. Mas em que medida tais discursos, referenciais e representações nos ajudam a identificar a conformação de uma memória social criada em torno e a partir das bibliotecas públicas? Responder a tal indagação converte-se na preocupação central da seção que se segue.

\section{Biblioteca pública, memória e Representações Sociais: um ESTUdo de CASo a PARTIR da Mário de Andrade}

Porque não posso dissociar minha experiência das bibliotecas, de um olhar lançado à biblioteca, não somente como depósito de livros e lugar de leitura, mas também como lugar de aprendizado e de sociabilidade.

(Goulemot, 20II, P.8).

Lugar de memória, Depósito de livros, Templo do saber, Espaço de leitura, Refúgio das musas, Catedral do conhecimento, estas são algumas das muitas representações 
e formulações simbólicas historicamente evocadas para se fazer menção às bibliotecas públicas. Instituições que desde suas origens passaram a ocupar um lugar de destaque no imaginário dos mais diversos tipos de leitores e usuários, se postando, neste sentido, como pólo edificador de referenciais mnemônicos compartilhados social e relacionalmente.

Constatação que nos incita a promover um exercício investigativo em torno do potencial simbólico que tais representações comportam e do que elas são capazes de nos dizer acerca do lugar social ocupado por determinada biblioteca em um período histórico específico, em um enquadramento político-cultural singular ou mesmo para uma comunidade de sujeitos que mantêm ou mantiveram algum nível de relação com a mesma. Para além das conjecturas, como levar a cabo uma análise dessa natureza? Em termos teórico-metodológicos, o campo da psicologia social e seus estudos sobre as estruturas representacionais oferece-nos interessantes chaves de leitura para os cenários acima descritos.

Os estudos das estruturas representacionais ganharam ampla visibilidade no campo da psicologia social após a publicação, entre os anos de 1961 e 1976, dos trabalhos fundadores de Serge Moscovici. Seu objetivo, já naquele período, era fazer frente à psicologia individualista norte-americana, pontuando que tal vertente desconsiderava as influências do "social" sobre os sujeitos individuais. Para tanto, retoma o conceito de representações coletivas ${ }^{6}$ de Durkheim e reelabora-o a partir das formulações propostas pela psicologia de Piaget e pela antropologia de Lévy-Brühl. Nessa mudança de paradigma, Moscovici torna explícito que seu interesse não é mais buscar compreender as representações erigidas por sociedades primitivas ou os fatos sociais que condicionavam os sistemas culturais de épocas remotas, mas sim as representações que se dão a ver em nossa sociedade presente, aquelas:

[...] do nosso solo político, científico e humano, que nem sempre tiveram tempo suficiente para permitir a sedimentação que as tornasse tradições imitáveis. E sua importância continua a crescer, em proporção direta à heterogeneidade e flutuação dos sistemas unificadores - ciências oficiais, religiões, ideologias - e às mudanças pelas quais eles devem passar a fim de penetrar na vida cotidiana e se tornar parte da realidade comum. (Moscovici, 1984, p.18-19 apud Castro, 2004, p.22).

6 Segundo Durkheim (1978, p.216): “as representações coletivas são o produto de uma imensa cooperação que se estende não apenas no espaço, mas no tempo; para fazê-las, uma multidão de espíritos diversos associaram, misturaram, combinaram suas ideais e sentimentos; longas séries de gerações acumularam aqui sua experiência e seu saber. Uma intelectualidade muito particular, infinitamente mais rica e mais complexa do que a do indivíduo, está aqui, portanto, como que concentrada”. 
Guinada teórico-conceitual ensejada graças à complexificação das sociedades contemporâneas e a irrupção de modos de vida pautados por outra ordem de fenômenos sociais, estes menos estáticos, coercitivos e estruturados que aqueles descritos por Durkheim. Isto porque, se para Durkheim as representações, sobretudo as coletivas, apresentavam-se como instâncias de valorização do simbólico coletivo tomadas enquanto princípio orientador da realidade social, emanando daí seu potencial sintetizador dos elementos dispersos no meio e na vida coletiva cujo produto remeteria à natureza supra-individual do homem ao postar-se como instrumento de intelecção do mundo e de comunicação/coesão entre as razões individuais que nele co-habitam, fazendo-se notar, assim, como formas estáveis da compreensão coletiva, as representações sociais na visada proposta por Serge Moscovici ligar-se-iam a formas de criações coletivas imersas no domínio das injunções políticas, culturais e históricas que caracterizam a modernidade. Nestes termos, a psicologia social moscoviciana reorienta a visada funcionalista dos pressupostos durkheimianos enfatizando que as estruturas representacionais não devem ser tomadas como unidades coesas que se legitimam através do seu poder de coerção uma vez que emergem e se fazem notar no âmbito dos pontos de conflitos instituídos e instituintes da própria cultura.

Portanto, mesmo compartilhando com Durkheim o pressuposto de que as representações referem-se tanto aos processos pelos quais são elaboradas, quanto às estruturas de conhecimento que se estabelecem com e a partir delas, Moscovici defende que as representações sociais, diferentemente das coletivas, instituem-se não apenas como modo de compreender um objeto particular, mas também como forma em que o sujeito (indivíduo ou grupo) adquire capacidade de definição das maneiras como as representações expressam seu valor simbólico. Assim colocado, para o nosso autor, as representações são sempre produto da interação e da comunicação que "tomam sua forma e configurações específicas a qualquer momento, como uma consequência do equilíbrio específico desses processos de influência social". (Duveen, 2003, p.21). Conjunção de elementos que serviu como ponto de partida para que Moscovici definisse as representações sociais como:

Um sistema de valores, idéias e práticas, com uma dupla função: primeiro, estabelecer uma ordem que possibilitará às sociedades orientar-se em seu mundo material e social e controlá-lo; e, em segundo lugar, possibilitar que a comunicação seja possível entre os membros de uma comunidade, fornecendo-lhes um código para nomear e classificar, sem ambigüidade, os vários aspectos de seu mundo e da sua história individual e social. (Moscovici, 1976, p.XIII apud Duveen, 2003, p.29). 
Neste sentido, além de realocar o estudo das representações para o plano do social, o autor acima citado institui três princípios metodológicos que diferenciam sua postura analítica em relação àqueles que o antecederam: reduzir a amplitude de formas de conhecimento presentes na teoria durkheimiana; compreender que os fenômenos sociais contemporâneos são móveis e não possuem contornos amplamente definidos e interpelar as representações sociais não como dados ou entidades explicativas absolutas, mas como fenômenos que apresentam tensões em suas estruturas e mecanismos internos.

Assim proposto, os fundamentos de sua teoria assinalam que as representações sociais nascem nas mesmas circunstâncias e ao mesmo tempo em que se manifestam. Ou seja, como resultante dos processos de interação entre os sujeitos e da experienciação dos referenciais simbólicos que informam e modulam a vida cotidiana. Não por acaso:

Las representaciones se manifiestan en el lenguaje y en las prácticas, en razón de su función simbólica y de los marcos que proporcionan para codificar e categorizar el mundo de la vida. En este sentido, podemos pensar que las representaciones sociales hacen posible abordar las concepciones e prácticas que orientan la experiencia de vida de los diferentes grupos poblacionales ${ }^{7}$. (Vergara Quintero, 2008, p.62).

Potencial orientador que se institui como resultado dos processos de interação vivenciados em universos simbólicos consensuais pautados por normas, regras, valores, experiências e associações internalizados para organizar tanto as vidas individuais, quanto as dinâmicas e ações coletivas. Contudo, é preciso deixar claro que essa internalização não se dá de maneira passiva, mas sim como ato ativo onde o "não familiar" é tornado familiar a partir de um conjunto de dinâmicas "em que objetos e eventos são reconhecidos, compreendidos com base em encontros anteriores”. (Leme, 2004, p.48). Familiaridade alcançada através de dois processos: a ancoragem e a objetivação.

O primeiro indica um exercício de associação em que grupos e sujeitos estabelecem uma relação de proximidade entre aquilo que ainda não está classificado e nem rotulado com imagens, categorias e explicações já conhecidas, aceitas socialmente. Trata-se, pois, de um movimento de categorização das coisas do mundo a partir de configurações simbólicas enraizadas em nos-

7 As representações se manifestam na linguagem e nas práticas, em razão de sua função simbólica e dos marcos que proporcionam para codificar e categorizar o mundo da vida. Neste sentido, podemos pensar que as representações sociais tornam possível abordar as concepções e práticas que orientam a experiência de vida dos diferentes grupos populacionais. (Tradução nossa). 
sa memória social e subjetiva. A objetivação, por sua vez, refere-se ao ato de transformar a associação abstrata inferida durante o processo de ancoragem em algo quase físico. Em termos representacionais, a objetivação denomina o ato de atribuir/descobrir o aspecto icônico de uma idéia. Nas palavras do próprio Moscovici:

Ancoragem e objetivação são, pois, maneiras de lidar com a memória. A primeira mantém a memória em movimento e a memória é dirigida para dentro, está sempre colocando e tirando objetos, pessoas e acontecimentos, que ela classifica de acordo com um tipo e os rotula com um nome. A segunda, sendo mais ou menos direcionada para fora, (para os outros), tira daí conceitos e imagens para juntá-los e reproduzi-los no mundo exterior, para fazer as coisas conhecidas a partir do que já é conhecido. (Moscovici, 2003, p.78).

Nesse movimento, em função do processo de ancoragem não se restringir ou não se postar exclusivamente ligado ao domínio intersubjetivo das emoções, as representações sociais não se apresentam como estruturas ou construções simbólicas fechadas sobre si mesmas. Por ser uma dimensão do conhecimento que se conjuga com aspectos que são da ordem daquilo que é experimentado social, histórica e culturalmente, essa modalidade de representação da realidade e do mundo da vida adquire contornos mais claros e congregadores quando apreendida no cerne das várias modalidades de relações estabelecidas entre os grupos e entre os indivíduos em geral. Não por acaso, a teoria das representações sociais busca explicar, descrever ou identificar as dinâmicas complexificadoras das sociedades contemporâneas adotando como ponto de partida as relações sociais, sem deixar de se ater ao caráter histórico-relacional que povoam as consciências e orientam as condutas individuais e coletivas, inclusive aqueles ligadas ao universo das memórias individuais e sociais. Conjunto de implicações que levou Denise Jodelet a apreender as representações sociais como:

[...] forma de conhecimento socialmente elaborada e uma realidade comum a um conjunto social. Embora muitas vezes interpretada como saber de senso comum ou ainda saber ingênuo, natural, essa forma de conhecimento é diferenciada, entre outras, do conhecimento científico. Entretanto, é tida como um objeto de estudo tão legítimo quanto este, devido à sua importância na vida social e à elucidação possibilitadora dos processos cognitivos e das interações sociais. Neste sentido, enquanto sistemas de interpretação que regem nossa relação com o mundo e com os outros, as representações sociais orientam e organizam as condutas e as interações sociais, da mesma forma que intervêm em processos variados, tais 
como a difusão e a assimilação dos conhecimentos, o desenvolvimento individual e coletivo, a definição das identidades pessoais e sociais, a expressão dos grupos e as transformações culturais. Em suma, enquanto fenômenos sociais, as representações envolvem a pertença social dos indivíduos com as implicações afetivas e normativas, com as interiorizações de experiências, práticas, modelos de conduta e pensamentos, socialmente inculcados ou transmitidos durante os processos de interação social, que a ela estão ligados. São, pois, produto e processo de uma atividade de apropriação da realidade exterior ao pensamento e de elaboração psicológica e social da realidade. (Jodelet, 2001, p.22).

As representações sociais são, assim, elaborações dinâmicas que se dão a ver tanto como resultado de injunções histórico-culturais, quanto formulações cotidianas relacionalmente estruturadas e imbuídas de forte senso orientador. Portanto, enquanto conceito que se transmuta em preceito teórico-metodológico, faz mais que refletir o mundo, que criar e manter um mundo social. Elas nos oferecem uma possibilidade de compreensão acerca das "distintas relaciones que pueden existir entre lo sociocultural y lo individual, y también de analizar a la persona como un participante cultural que es simultáneamente una construcción social y un constructor social de experiencia". (Vergara Quintero, 2008, p.73). Assim colocado, cabe-nos aqui levantar as seguintes indagações: em que medida as representações sociais erigidas em torno da biblioteca pública nos ajuda a apreender o lugar social por ela ocupado no cerne de um sistema sócio-cultural e histórico específico? Elas nos permitem identificar as atribuições de sentido e os elementos simbólico-afetivos responsáveis por compor um universo mnemônico socialmente compartilhado entre seus leitores e usuários?

Tentaremos responder a tais questões promovendo uma análise dos depoimentos de $8^{9}$ (oito) personalidades inseridas no cenário intelectual paulistano acerca da Biblioteca Pública Mário de Andrade. Inscritos sobre a

8 Distintas relações que podem existir entre o sócio-cultural e o individual, e também de analisar a pessoa como um participante cultural que é simultaneamente uma construção social e um construtor social de experiência. (tradução nossa).

9 São eles: Anna Verônica Mautner (psicanalista); Aziz Ab’Saber (geógrafo e professor universitário); Fernando Henrique Cardoso (sociólogo, professor universitário e Ex-Presidente da República); Ignácio de Loyola Brandão (escritor); Jean-Claude Bernardet (crítico de cinema); Marilena Chauí (filósofa, professora universitária e Ex-Secretária de Cultura de São Paulo); Mario Chamie (poeta, ensaísta e Ex-Secretário de Cultura de São Paulo) e Ruth Cardoso (antropóloga e professora universitária). Em seu conjunto, portanto, estes depoentes constituemse em um grupo sui generis de interlocutores que nos permite apreender, a partir de sua fala e percursos mnemônicos, uma série de vestígios que compõem um mosaico mais geral do lugar ocupado pela BMA na constituição dos referenciais que alimentam a formação de um discurso identitário intersubjetivo, assim como relacionamentos e ações práticas que, localizadas em um plano sócio-cultural, ajudam a contar/recontar a própria história paulistana entre os anos de 1940-1980. 
forma de relatos de vida, esses depoimentos compõem um rico mosaico de referências e representações sócio-históricas que nos permite identificar o lugar ocupado por essa biblioteca no panorama cultural de São Paulo e sua participação na conformação de uma memória social compartilhada entre os depoentes. Além disso, nos ajuda a reunir argumentos para demonstrar de maneira mais enfática que uma biblioteca só adquire sentido a partir do trabalho de seus leitores e usuários, ponto de partida desse artigo.

Fundada em 1925 como biblioteca Municipal de São Paulo, a Mário de Andrade é a primeira biblioteca pública da cidade e a segunda maior do país. Foi inaugurada em 1926, na Rua 7 de Abril, com uma coleção inicial formada por obras doadas pela Câmara Municipal de São Paulo. Em 1937, incorporou a Biblioteca Pública do Estado e, a partir de então, importantes aquisições de livros, muitos deles raros e especiais, enriqueceram sua coleção. $\mathrm{O}$ crescimento de seu acervo e serviços ocasionou a mudança da Biblioteca para o atual edifício, localizado na Rua da Consolação, que foi projetado pelo arquiteto francês Jacques Pilon e é considerado um marco da arquitetura Art Déco paulista.

Entre os serviços que oferece, destacam-se pelo pioneirismo a Seção de Artes, que reúne coleções especializadas de livros, revistas e reproduções; a Seção infantil e Infanto-Juvenil, criada em 1952; e as ações do carro-biblioteca, o primeiro do país. Seu acervo atual conta com aproximadamente 3,3 milhões de itens, entre livros, periódicos, mapas e multimeios. Além disso, a Biblioteca Mário de Andrade mantém grandes coleções especiais, que incluem um dos maiores acervos de livros de arte de São Paulo, uma biblioteca depositária da ONU e uma riquíssima coleção de obras raras, considerada a segunda maior coleção pública do Brasil. Merece destaque, ainda, a Coleção São Paulo, que tem por objetivo ser um dos pilares informacionais, de pesquisa e referência sobre a cidade, razão pela qual reúne um grandioso acervo de materiais audiovisuais e bibliográficos sobre São Paulo, dando ênfase à sua arte, arquitetura e cultura geral.

Ao longo de sua história inúmeros usuários se formaram enquanto leitores e intelectuais tendo como ponto de referência suas coleções e o espaço de sociabilidade que se criou no perímetro de suas dependências. Em virtude disso, ocupa hoje lugar privilegiado na vida e na história de diversos sujeitos, congregando em torno de si um universo de representações simbólicas que, em um plano mais geral, fomenta a constituição de uma memória social compartilhada. Como podemos demonstrar isso?

Durante a leitura dos depoimentos, algumas referências discursivas puderam ser identificadas em todos eles: a importância da $B M A$ como marco representativo e difusor de cultura; sua relevância para a polarização e mobilização 
da vida cultural paulistana entre as décadas de 1940 e 1980; o impacto que os depoentes expressam frente à imponência do prédio e a quantidade de obras nele preservadas; o reconhecimento da biblioteca como um espaço de sociabilidade responsável por estabelecer o contato entre sujeitos vindos de diferentes bairros da cidade e portadores de condições de vida também diversificas. Contudo, nenhuma representação se expressa de maneira tão concreta como as que se reportam à Mário de Andrade enquanto "lugar de leitura, educação e formação intelectual". Existe quase que um consenso entre os depoentes de que o espaço e as atividades desenvolvidas pela biblioteca se constituíram para cada um deles em experiência tão marcante, em termos de desenvolvimento pessoal, quanto a universidade ou outros pólos de produção de referências simbólicos como a família, os partidos políticos e seus espaços de trabalho. É isso que nos mostra a tabela abaixo apresentada. 


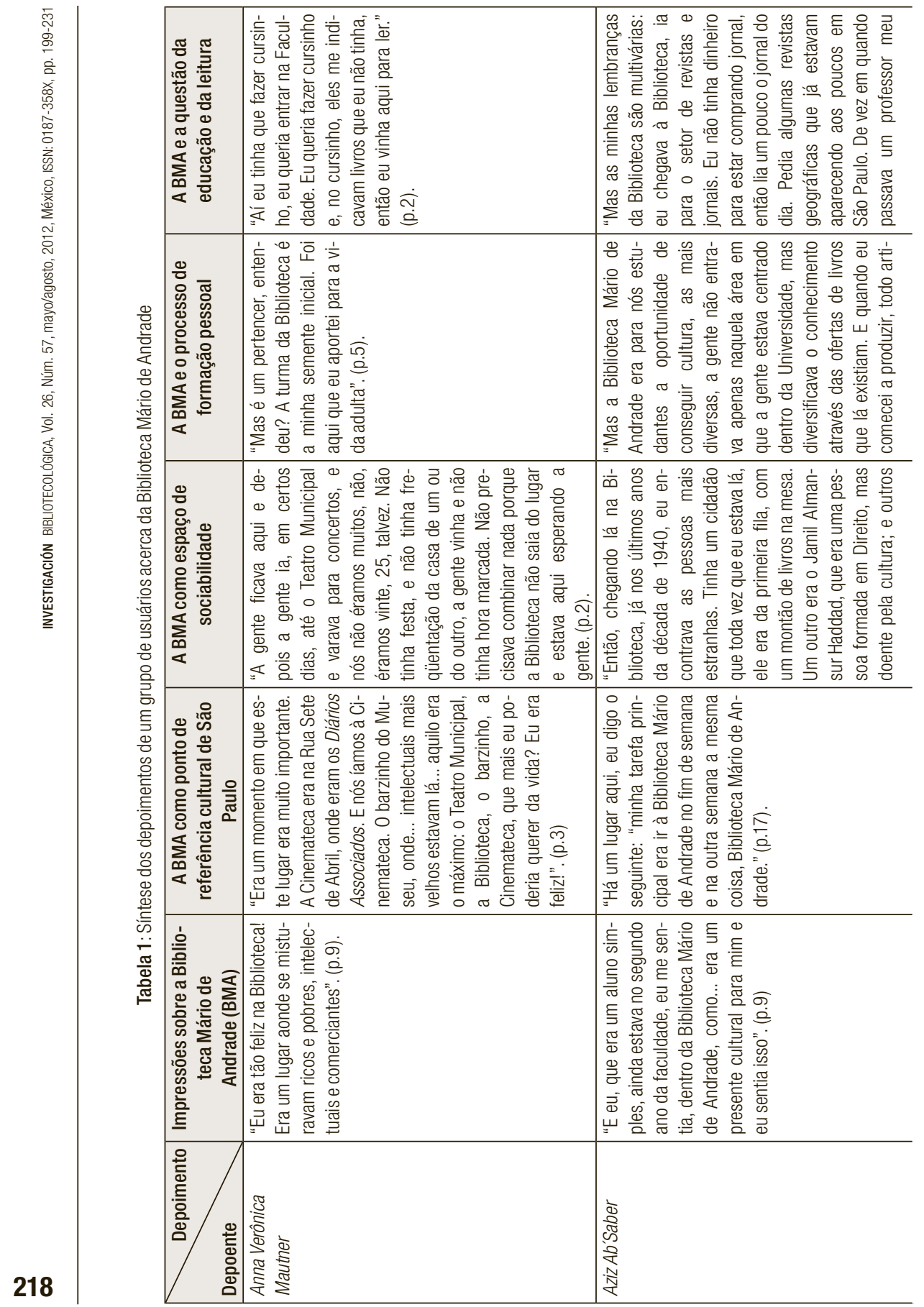




\begin{tabular}{|c|c|c|}
\hline 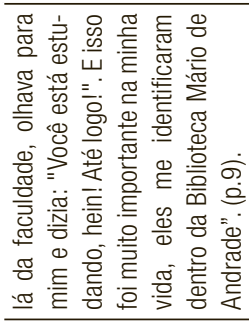 & 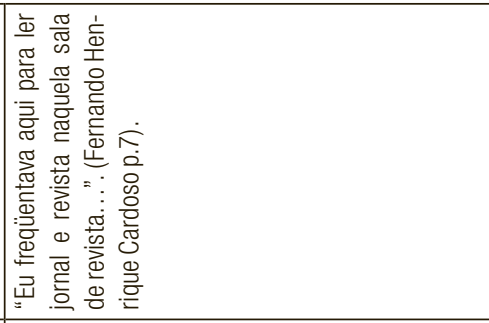 & 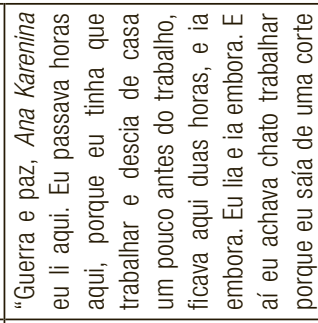 \\
\hline 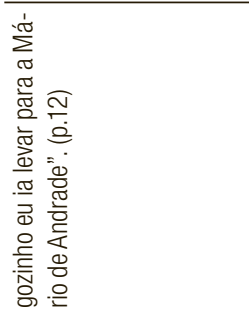 & 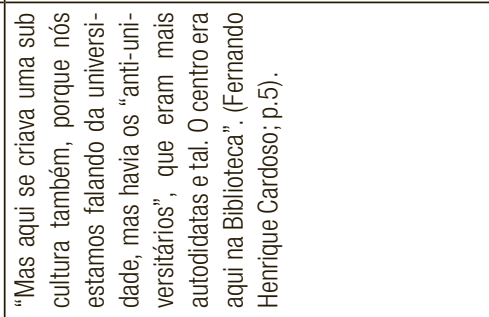 & 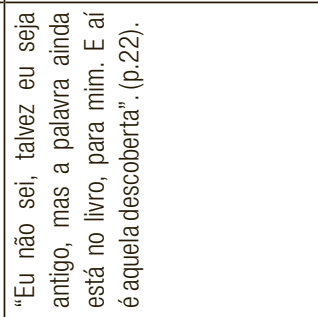 \\
\hline \multirow[t]{4}{*}{ 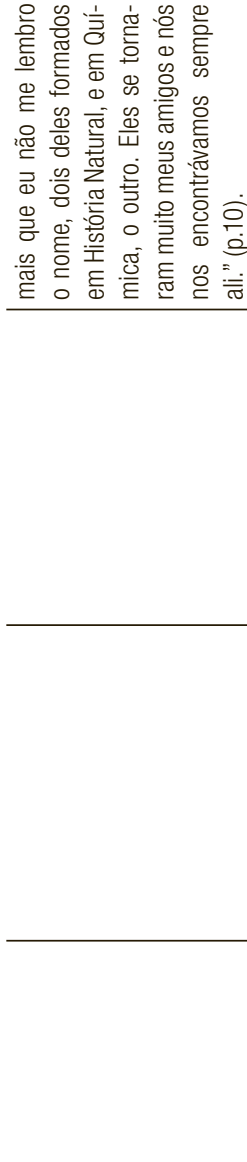 } & 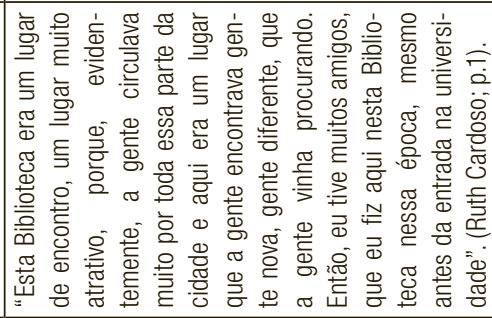 & 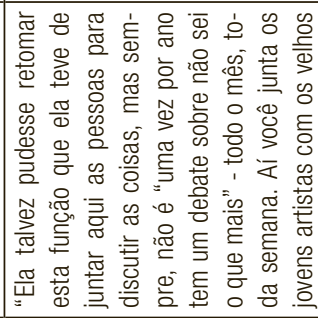 \\
\hline & 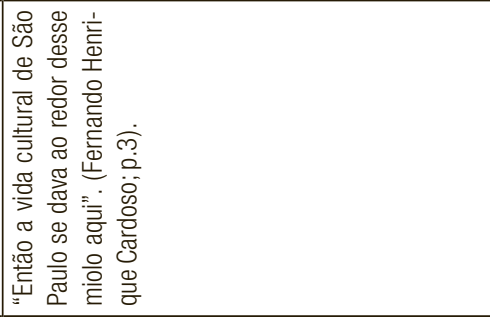 & 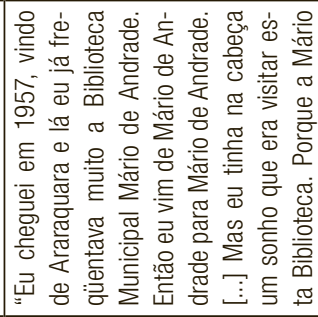 \\
\hline & 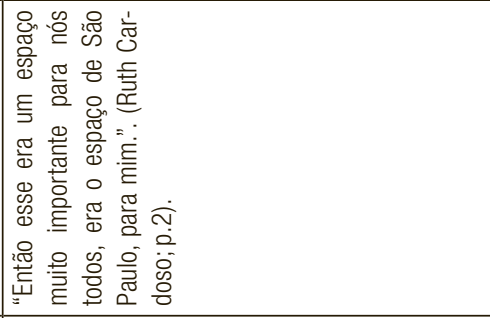 & 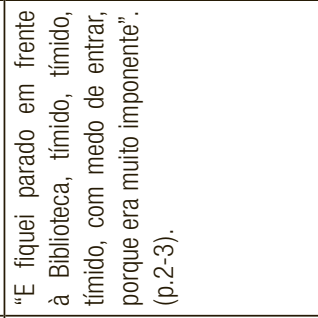 \\
\hline & 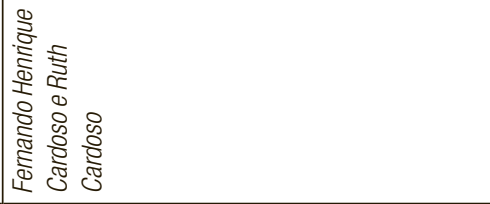 & 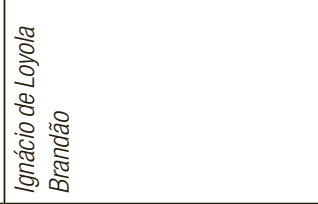 \\
\hline
\end{tabular}




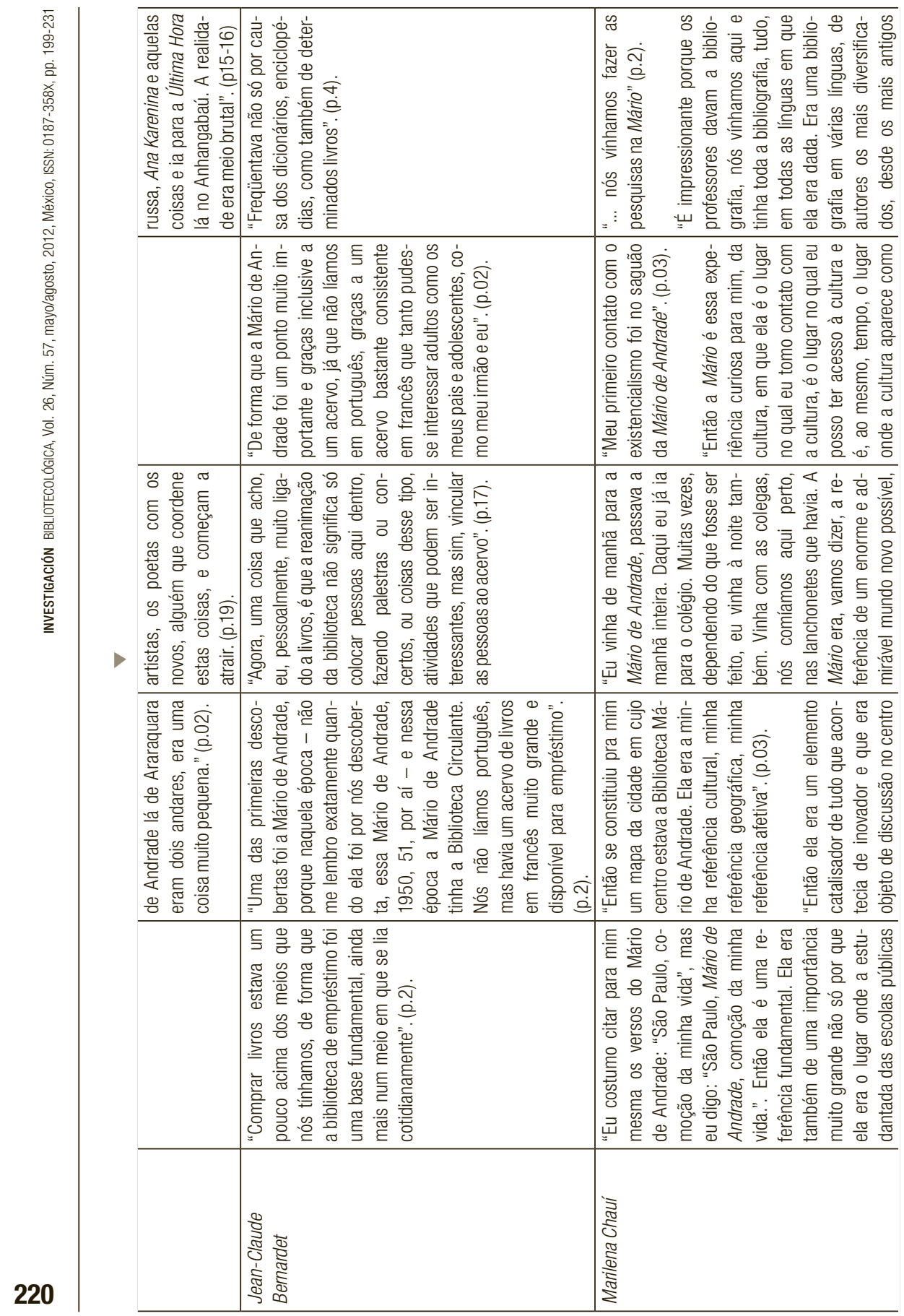




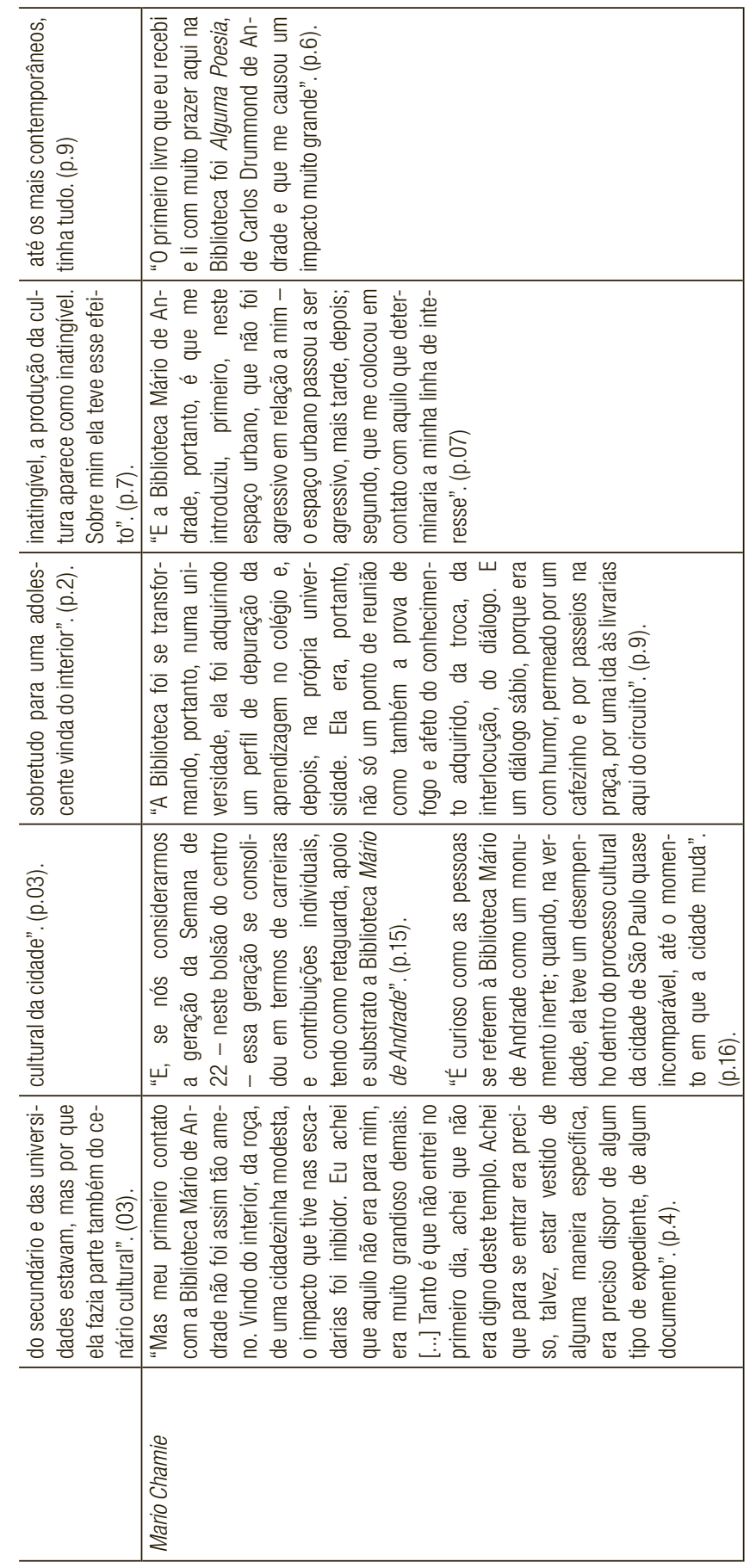


Tendo como pano de fundo os aportes teóricos anteriormente apresentados, depoimentos como os de Anna Verônicas Mautner: "mas é um pertencer, entendeu? A turma da Biblioteca é a minha semente inicial. Foi aqui que eu aportei para a vida adulta"; ou as palavras de Ruth Cardoso: "então esse era um espaço muito importante para nós todos, era o espaço de São Paulo, para mim", por exemplo, nos permite dizer que a $B M A$ certamente ocupa um lugar de acentuado destaque no imaginário individual de cada um dos depoentes e que tal lugar se deve, em ampla medida, às objetivações que os mesmos erigiram em torno dela, definindo-a ora como lugar de cultura e espaço de sociabilidade, ora como instância de formação individual alcançada graças às práticas educacionais e às atividades de leitura que ali experienciaram. Modalidade de compreensão que encontra ressonância e sustentação nas seguintes afirmativas de Jovchelovitch (2007, p.65):

As representações sociais, enquanto fenômeno psicossocial, estão necessariamente radicadas no espaço público e nos processos através dos quais o ser humano desenvolve uma atividade, cria símbolos e se abre para a diversidade de um mundo de outros. [...] A esfera pública, enquanto lugar da alteridade, fornece às representações o terreno sobre o qual elas podem ser cultivadas e se estabelecer.

Por sua vez, a declaração de Ignácio de Loyola Brandão: "e fiquei parado em frente à Biblioteca, tímido, tímido, tímido, com medo de entrar, porque era muito imponente" ou a pontuação de Mario Chamie:

mas meu primeiro contato com a Biblioteca Mário de Andrade não foi assim tão ameno. Vindo do interior, da roça, de uma cidadezinha modesta, o impacto que tive nas escadarias foi inibidor. Eu achei que aquilo não era para mim, era muito grandioso demais. [...] Tanto é que não entrei no primeiro dia, achei que não era digno deste templo. Achei que para se entrar era preciso, talvez, estar vestido de alguma maneira específica, era preciso dispor de algum tipo de expediente, de algum documento.

nos incita a justificar o estranhamento de todos eles frente à imponência do prédio e à magnitude do acervo em função de referenciais históricos ancorados socialmente e que apontam para uma realidade sócio-cultural que só tardiamente passou a ser impregnada pela presença de livros e espaços públicos como as bibliotecas.

De fato, a presença de bibliotecas públicas em terras brasileiras só começa a ser notada por volta dos anos 1930. Assim como na Inglaterra, as primeiras que por aqui surgiram carregavam consigo a missão de auxiliar no 
processo de formação educativa do contingente populacional que migrava para as cidades em função do intenso processo de industrialização que alterou sobremaneira a paisagem urbana e o modo de vida dos grandes centros econômicos do país. Contudo, diferentemente do que ocorreu na Europa e nos Estados Unidos, tais instituições, em sua maioria, se mantiveram mal equipadas, padeceram pela inexistência de investimento político-financeiro e não alcançaram os resultados que delas se esperava. Além disso, se converteram, pelo menos em um primeiro momento, em espaço de socialização de homens ricos e letrados ou de uma classe média ascendente. Então, por que os depoentes não deveriam estranhar quando chegavam à BMA?

Contudo, é preciso que não desconsideremos o que nos diz Aziz Ab’Saber e Marilena Chauí:

Mas a Biblioteca Mário de Andrade era para nós estudantes a oportunidade de conseguir cultura, as mais diversas, a gente não entrava apenas naquela área em que a gente estava centrado dentro da Universidade, mas diversificava o conhecimento através das ofertas de livros que lá existiam. E quando eu comecei a produzir, todo artigozinho eu ia levar para a Mário de Andrade. (Ab’Saber, 2008).

Eu vinha de manhã para a Mário de Andrade, passava a manhã inteira. Daqui eu já ia para o colégio. Muitas vezes, dependendo do que fosse ser feito, eu vinha à noite também. Vinha com as colegas, nós comíamos aqui perto, nas lanchonetes que havia. A Mário era, vamos dizer, a referência de um enorme e admirável mundo novo possível, sobretudo para uma adolescente vinda do interior. [...] Então se constituiu pra mim um mapa da cidade em cujo centro estava a Biblioteca Mário de Andrade. Ela era a minha referência cultural, minha referência geográfica, minha referência afetiva. (Chauí, 2006).

Que referência é essa ressaltada pelo geógrafo e também pela eminente filósofa? A partir dos depoimentos aqui arrolados, podemos responder a essa questão nos valendo de quatro representações alçadas pelos depoentes para se referenciar à BMA: lugar de cultura; espaço de sociabilidade; instância de formação intelectual e ambiente de educação e leitura.

Lugar de cultura refere-se, para nossos interlocutores, a um ambiente catalisador do universo simbólico responsável por inseri-los no seio de uma tradição ou no conjunto de referências que apontam para uma memória forjada e experienciada socialmente. Diz também do lugar, o ponto de referência da cidade onde esse universo simbólico transformava-se em práticas e manifestações que podiam ser vivenciadas coletivamente. Condição que nos leva à segunda representação: espaço de sociabilidade: ambiente de encontros fortuitos 
ou planejados, de troca de idéias e de interações que acabaram sedimentando amizades, inspirando amores - o de Ruth e Fernando Henrique Cardoso, por exemplo - e aproximando vidas. As duas últimas se aproximam e possuem características comuns: refere-se ao lugar onde nossos personagens se formaram para o mundo e puderam travar contato com o mundo: o mundo dos livros, das escolas de pensamento, das ideologias e também dos paradoxos, das palavras que inspiram e das histórias que por vezes confundem, deformam os sonhos, mas que por outras, alimentam e curam a alma. Dito isso, é possível afirmarmos que essas quatro representações acima descritas estruturam as bases de um mundo comum ${ }^{10}$ para nossos depoentes. Um mundo comum que tem como centro a BMA e suas representações socialmente compartilhadas. Desta feita, as relações entre bibliotecas públicas, memória e representações sociais se tornam mais claras quando passamos a compreender que:

As representações sociais são uma estratégia desenvolvida por atores sociais para enfrentar a diversidade e a mobilidade de um mundo que, embora pertença a todos, transcende a cada um individualmente. Nesse sentido, elas são um espaço potencial de fabricação comum, onde cada sujeito vai além de sua individualidade para entrar em um domínio diferente, ainda que fundamentalmente relacionado: o domínio da vida em comum (Jovchelovitch 2007, p.65).

Sendo assim, seja refletindo sobre seu espaço físico, seja retomando, recordando práticas que foram vivenciadas no seu interior ou ainda avaliando os sentidos simbólicos e afetivos que projetam para a Biblioteca Mário de Andrade, é inegável que os depoentes com os quais dialogamos apontam para a conformação de uma memória social erigida em torno e a partir dessa biblioteca pública. Uma memória ativa, estruturada relacional e contextualmente. Uma memória subjetiva, mas que não dispensa a presença do outro. Um "outro" que possui como ponto de referência a BMA e o que ela congrega, comporta em termos representacionais e mnêmicos.

10 Quando dizemos mundo comum estamos fazendo referência direta ao pensamento de Hannah Arendt, para quem "o mundo comum é aquilo que adentramos ao nascer e que deixamos para trás quando morremos. Transcende a duração de nossa vida tanto no passado quanto no futuro: preexistia à nossa chegada e sobreviverá à nossa breve permanência. É isto o que temos em comum não só com aqueles que vivem conosco, mas também com aqueles que aqui estiveram antes e aqueles que virão depois de nós. Mas esse mundo comum só pode sobreviver ao advento e à partida das gerações na medida em que tem uma presença pública”. (Arendt, 1991, p. 65) 


\section{Considerações finais}

Uma biblioteca, real ou mental, representa a maior e mais preciosa fonte de inspiração.

(GOULEMot, 20II, P.227).

As bibliotecas públicas são definidas pela literatura acadêmica como instituições portadoras de 4 (quatro) funções sociais básicas: a cultural, a informacional, a recreativa e a educacional. Modalidade de compreensão que estabelece para essas instituições a necessidade de se converterem em espaço que promove a difusão e dá visibilidade às produções culturais humanas, que faz da informação um insumo a ser captado, preservado e disponibilizado em prol da produção de conhecimento, inclusive por meio de atividades lúdicas e recreativas capazes de fomentar o surgimento de uma atmosfera propícia ao exercício da imaginação e da criatividade, bem como o reforço e a equalização das práticas educativas e da leitura.

Desenvolvendo-se sobre a égide desses quatro pilares, as bibliotecas públicas ganharam projeção e se converteram, ao menos em terras brasileiras:

No mais importante equipamento cultural do ponto de vista da incidência municipal, o que abre a possibilidade de um maior entendimento sobre o seu papel como veiculador de conteúdos culturais, não apenas diretamente ligados à leitura, mas a outras possibilidades de acessos mais amplos, como vídeos, Internet, CDs, DVDs, etc. [...] As bibliotecas públicas encontram-se em 89,1\% (4955 dos 5564) dos municípios brasileiros, ainda em processo de expansão, mostrando-se um equipamento central e sujeito à atenção dos gestores públicos, pois podem, além do fomento à leitura, servir como infra-estrutura para outros conteúdos audiovisuais, musicais, além de apresentações, cursos e palestras que se sirvam deste equipamento. A despeito do elevado percentual de sua existência nos municípios, as bibliotecas ampliaram em $16,8 \%$ a sua incidência municipal entre 1999 e 2006. (IBGE, 2006, p.100-112). (Destaque nosso).

Contudo, para além das diretrizes acadêmicas e da justeza dos números, outro elemento se torna indispensável à tentativa de se definir o que é uma biblioteca pública e de se apreender o lugar social ocupado por ela no seio de uma dada sociedade: trata-se do olhar e dos sentidos simbólicos que lhes são atribuídos por seus leitores e usuários. Isto porque, são eles que, em última instância, legitimam suas ações, se apropriam de seus acervos, desvirtuam certos preceitos e encaminhamentos político-ideológicos sobre os quais elas se assentam e que também ajudam a sedimentar intricados padrões de sociabilidade erigidos em torno de si. 
Padrões de sociabilidade que, por sua vez, se polarizam e se fazem notar através de uma série de ações prático-discursivas: é o caso das comunidades de leitores; dos grupos de estudos que se formam em seu interior; das sociedades de amigos da biblioteca e também das representações sociais e referenciais mnemônicos mobilizados e compartilhados por um conjunto de usuários para se reportar a uma instituição específica. Foi isso que tentamos demonstrar a partir dos 8 (oito) depoimentos aqui arrolados.

Tendo como elemento desencadeador do trabalho mnêmico o cenário e as experiências vivenciadas na e a partir da BMA, os depoentes acabaram por formatar um rico mosaico sócio-histórico e cultural da vida paulistana entre os anos de 1940-1980, cujo marco simbólico-geográfico era a própria biblioteca. Razão pela qual a descrevem, concomitantemente, como lugar de cultura, espaço de sociabilidade, instância de formação intelectual e ambiente de educação e leitura. Representações objetivadas por um grupo de usuários que viveram em um período de intensa efervescência cultural, que compartilharam sonhos, medos e frustrações, mas que, recordando-os e vinculandoos a um universo de sentido estruturado afetiva e relacionalmente como o da Biblioteca Mário de Andrade, definem também, e a um só tempo, o lugar ocupado por instituições como essa na trama dos episódios, referências e acontecimentos que marcam a vida de um sujeito ou mesmo de uma coletividade inteira. Marcas que encontram sua síntese na seguinte formulação de Mário Chamie (2006, p.9):

A Biblioteca foi se transformando, portanto, numa universidade, ela foi adquirindo um perfil de depuração da aprendizagem no colégio e, depois, na própria universidade. Ela era, portanto, não só um ponto de reunião como também a prova de fogo e afeto do conhecimento adquirido, da troca, da interlocução, do diálogo. E um diálogo sábio, porque era com humor, permeado por um cafezinho e por passeios na praça, por uma ida às livrarias aqui do circuito (p. 9).

Assim manifesto, cabe-nos aqui levantar uma última questão: poder-seá utilizar o quadro contextual acima apresentado como situação exemplar toda vez que se quiser discutir a participação das bibliotecas públicas no processo de edificação de memórias sociais compartilhadas relacionalmente?

Certamente que não. O estudo aqui desenvolvido faz menção e busca apreender os traços e contornos de uma memória social que distingue um grupo de usuários específicos e que está calcada em representações também específicas, por isso, talvez, não possua um poder de generalização capaz de sintetizar as transformações que complexificaram ainda mais as relações sociais contemporâneas, sobretudo após os anos 1990. Contudo, ao enfatizar 
que nem a memória, nem as representações sociais são construções rígidas e engessadas no tempo, o mesmo pode servir de ponto de partida para que outros estudos sejam feitos e para que outros panoramas explicativos acerca das relações entre bibliotecas públicas, memória e representações sociais sejam projetados e desvelados.

\section{REFERÊNCIAS E FONTES}

\subsection{Referências}

Arendt, Hannah. A condição bumana. 5. ed. Rio de Janeiro: Forense Universitária, 1991. Entre o passado e o futuro. São Paulo: Perspectiva, 2002. (Debates; 64).

Baratin, Marc; Jacob, Christian (Orgs.). O poder das bibliotecas: a memória dos livros no ocidente. Rio de Janeiro: UFRJ, 2000.

Bosi, Ecléa. Memória e sociedade: lembrança de velhos. 11 ed. São Paulo: Companhia das Letras, 2004.

- O tempo vivo da memória: ensaios de psicologia social. 2 ed. São Paulo: Ateliê, 2003.

Cuzcano, Alonso Estrada. La biblioteca pública: institución democrática al servicio de los ciudadanos. Inf. E Soc.: Est., João Pessoa, 2002, v.12, n.2, p.41-59.

Doise, W. Les représentations sociales: définition d'un concept. Connexions, n.45, p.245-253, 1985.

Durkheim, Émile. Formas elementares da vida religiosa: o sistema totêmico na Austrália. In: Émile Durkheim. São Paulo: Abril Cultural, 1978, p.203-245. (Os pensadores).

Duveen, Gerard. O poder das ideias. In: Moscovici, Serge. Representações sociais: investigações em psicologia social. 4 ed. Petrópolis: Vozes, 2003, p.7-28.

Flusser, Víctor. Uma biblioteca verdadeiramente pública. Revista da Escola de Biblioteconomia da UFMG, Belo Horizonte, v.9, n.2, p.131-1387, set. 1980.

Goulemot, Jean Marie. O amor às bibliotecas. São Paulo: UNESP, 2011.

Guareschi, Pedrinho; Jovchelovitch, Sandra (Orgs.). Textos em representações sociais. 9 ed. Petrópolis: Vozes, 2007.

Halbwachs, Maurice. A memória coletiva. São Paulo: Centauro, 2006. Les cadres sociaux de la memóire. Paris: Presse Universitaires de France, 1952.

IBGE. Pesquisa de informações básicas municipais: perfil dos municípios brasileiros - cultura, 2006. Rio de Janeiro: IBGE, 2007.

Jacob, Christian. Ler para escrever: navegações alexandrinas. In: Baratin, Marc; Jacob, Christian (Orgs.). O poder das bibliotecas: a memória dos livros no ocidente. Rio de Janeiro: UFRJ, 2000, p.45-73. 
Prefácio. In: Baratin, Marc; Jacob, Christian (Orgs.). O poder das bibliotecas: a memória dos livros no ocidente. Rio de Janeiro: UFRJ, 2000, p.9-17.

Rassembler la mémoire: réflexions sur l'histoire des bibliothèques. Diogène, 2001/04, n.196, p.53-76.

Jodelet, Denise (Org.). As representações sociais. Rio de Janeiro: UERJ, 2001.

Les représentations sociales dans le chanp de la culture. Social Science Information, Londres, 2002, n.41(1), p.111-133.

Memóire de masse: le côté moral et affectif de l'histoire. Bulletin de psychologie, n.405, p.239-256, 1992.

Jovchelovitch, Sandra. Vivendo a vida com os outros: intersubjetividade, espaço público e representações sociais. In: Guareschi, Pedrinho; Jovchelovitch, Sandra (Orgs.). Textos em representações sociais. 9 ed. Petrópolis: Vozes, 2007, p.63-85.

Le Goff, Jacques. História e memória. 5 ed. Campinas: UNICAMP, 2003.

Leme, Maria Alice Vanzolini da Silva. O impacto da teria das representações sociais. In: SPINK, Mary Jane Paris. O conbecimento no cotidiano: as representações sociais na perspectiva da psicologia social. São Paulo: Brasiliense, 2004, p.46-57.

Lovisolo, Hugo. A memória e a formação dos homens. Estudos históricos, Rio de Janeiro, v.2, n.3, 1989, p.16-28.

Manguel, Alberto. A biblioteca à noite. São Paulo: Companhia das Letras, 2006.

Martins, Estevão C. de Rezende. O enigma do passado: construção social da memória histórica. Textos de hitória, v.15, n.1/2, 2007, p.35-48.

Martins, Wilson. A palaura escrita: bistória do livro, da imprensa e da biblioteca. 3 ed. São Paulo: Ática, 2002. (Temas; 49).

Middleton, David; Brown, Steven. A psicologia social da experiência: a relevância da memória. Pro-Posições, v.17, n.2(50), maio/ago. 2006, p.71-97.

Moscovici, Serge. Das representações coletivas às representações sociais: elementos para uma história. In: Jodelet, Denise (Org.). As representações sociais. Rio de Janeiro: UERJ, 2001, p.45-66.

Representações sociais: investigações em psicologia social. 4 ed. Petrópolis: Vozes, 2003.

Müller, Suzana P. M. Biblioteca e sociedade: evolução da interpretação das funções e papéis da biblioteca. R. Esc. Bibliotecon. Ufmg. Belo Horizonte, 13(1): 7-54, mar. 1984.

Nora, Pierre. Entre memória e história: a problemática dos lugares. Proj. História, São Paulo, (10), dez. 1993, p.7-28.

Pinheiro Filho, Fernando. A noção de representação em Durkheim. Luanova, n.61, 2004, p.139-155. Disponível em: http://www.scielo.br/pdf/ln/n61/a08n61.pdf, Acessado: 15/04/2012. 
Pollak, Michel. Memória e identidade social. Estudos históricos, Rio de Janeiro, v.5, n.10, 1992, p.200-212.

Rêses, Erlando da Silva. Do conhecimento sociológico à teoria das representações sociais. Sociedade e cultura, jul./dez., v.6, n.2, 2003, p.189-199.

Roussiau, Nicolas; Renard, Elise. Des représentations sociales à l'institutionnalisation de la mémoire sociale. Connexions, v.80, n.2, p.31-41, 2003.

Sá, Celso Pereira de (Org.). Memória, imaginário e representações sociais. Rio de Janeiro: Museu da República, 2005. (Memória Social).

Sá, Celso Pereira de [et al]. A memória histórica do regime militar ao longo de três gerações no Rio de Janeiro: sua estrutura representacional. Estudos de psicologia, Campinas, 26(2), p.159-171, abr./ jun., 2009.

Sá, Celso Pereira de. A construção do objeto de pesquisa em representações sociais. Rio de Janeiro: EDUERJ, 1998.

- A memória histórica numa perspectiva psicossocial. Morpheus: revista eletrônica em ciências humanas, ano 09, n.14, 2009, p.91-100.

Representações sociais: o conceito e o estado atual da teoria. In: SPINK, Mary Jane Paris. O conbecimento no cotidiano: as representações sociais na perspectiva da psicologia social. São Paulo: Brasiliense, 2004, p.19-45.

Sobre o campo de estudo da memória social: uma perspectiva psicossocial. Psicologia: reflexão e crítica, 20(2), 290-295, 2007.

Santos, Myriam Sepúlveda dos. O pesadelo da amnésia coletiva: um estudo sobre os conceitos de memória, tradição e traços do passado. Cadernos de sociomuseologia, Portugal, n.19, 2002, p.121-150. . Memória coletiva e teoria social. São Paulo: AnnaBlume, 2003.

Seixas, Jacy Alves de. Percursos de memórias em terras de história: problemáticas atuais. In: Bresciani, Stella; Naxara, Márcia (Orgs.). Memória e (res) sentimento: indagações sobre uma questão sensível. 2. ed. Campinas: UNICAMP, 2004, p.37-58.

Serrai, Alfredo. História da biblioteca como evolução de uma idéia e de um sistema. R. Esc. Bibliotecon. UfMG, Belo Horizonte, 4(2) : 141-161, set. 1975.

Silveira, Fabrício José Nascimento da. Biblioteca como lugar de práticas culturais: uma discussão a partir dos currículos de Biblioteconomia no Brasil. 2007. 246f. Dissertação (Mestrado em Ciência da Informação) - Escola de Ciência da Informação da Universidade Federal de Minas Gerais, Belo Horizonte, 2007.

Biblioteca, memória e identidade social. Perspectivas em Ciência da Informação, v.15, n.3, p.67-86, set./dez, 2010. 
REIS, Alcenir Soares dos. Biblioteca como lugar de práticas culturais: uma discussão sócio-histórica. Inf. E Soc.: Est., João Pessoa, v.21, n.1, p. 37-54, jan./abr. 2011.

Souchu, Philippe. Memóire(s) \& bibliothèques. BBF, Paris, v.44, n.5, p.99-102.

Sperber, Dan. O estudo antropológico das representações: problemas e perspectivas. In: Jodelet, Denise (Org.). As representações sociais. Rio de Janeiro: UERJ, 2001, p.91-103.

Spink, Mary Jane Paris. O conbecimento no cotidiano: as representações sociais na perspectiva da psicologia social. São Paulo: Brasiliense, 2004.

UNESCO. Manifesto da UNESCO sobre bibliotecas públicas. Novembro, 1994.

Vergara Quintero, María Del Carmen. La naturaleza de las representaciones sociales. Rev. Latinoam. Cienc. Soc. Niñez. Juv. 6(1), p.5580, 2008.

\subsection{Fontes}

Ab’Saber, Aziz. São Paulo, Brasil, 18 fev. 2008, registro audiovisual. Entrevista concedida a Sérgio Teichner e Ana Elisa Antunes Viviani para o Projeto Memória Oral da Biblioteca Mário de Andrade. Disponível em: www.bma.sp.gov.br; Acessado em: 28/07/2011.

Bernardet, Jean Claude. São Paulo, Brasil, 22 jun. 2007, registro audiovisual. Entrevista concedida a Sérgio Teichner e Ana Elisa Antunes Viviani para o Projeto Memória Oral da Biblioteca Mário de Andrade. Disponível em: www.bma.sp.gov.br; Acessado em: 28/07/2011

Brandão, Ignácio de Loyola. São Paulo, Brasil, 12 jun. 2006, registro audiovisual. Entrevista concedida a Sérgio Teichner e Dayse Perelmutter para o Projeto Memória Oral da Biblioteca Mário de Andrade. Disponível em: www.bma.sp.gov.br; Acessado em: 28/07/2011.

Cardoso, Fernando Henrique; Cardoso, Ruth. São Paulo, Brasil, 22 mar. 2005, registro audiovisual. Entrevista concedida a Eugênio Puppo e Dayse Perelmutter para o Projeto Memória Oral da Biblioteca Mário de Andrade. Disponível em: www.bma.sp.gov.br; Acessado em: 28/07/2011.

Chamie, Mário. São Paulo, Brasil, 18 jun. 2006, registro audiovisual. Entrevista concedida a Sérgio Teichner e Dayse Perelmutter para o Projeto Memória Oral da Biblioteca Mário de Andrade. Disponível em: www.bma.sp.gov.br; Acessado em: 28/07/2011.

Chauí, Marilena. São Paulo, Brasil, 19 jul. 2006, registro audiovisual. Entrevista concedida a Sérgio Teichner, Lúcia Neíza e Dayse Perelmutter para o Projeto Memória Oral da Biblioteca Mário de Andrade. Disponível em: www.bma.sp.gov.br; Acessado em: 28/07/2011 
Mautner, Anna Verônica. São Paulo, Brasil, 09 ago. 2006, registro audiovisual. Entrevista concedida a Sérgio Teichner e Dayse Perelmutter para o Projeto Memória Oral da Biblioteca Mário de Andrade. Disponível em: www.bma.sp.gov.br; Acessado em: 28/07/2011.

$\infty$ 